Article

\title{
Fractionation of Waste MDF by Steam Refining
}

\author{
Sebastian Hagel and Bodo Saake *(1) \\ Institute of Wood Science, Chemical Wood Technology, Universität Hamburg, Haidkrugsweg 1, 22885 Barsbüttel, \\ Germany; Sebastian.Hagel@uni-hamburg.de \\ * Correspondence: Bodo.Saake@uni-hamburg.de; Tel.: +49-40-822-459-206
}

Academic Editors: Jalel Labidi and Xabier Erdocia

Received: 27 March 2020; Accepted: 2 May 2020; Published: 5 May 2020

\begin{abstract}
In view of the expected increase in available waste medium-density fiberboard (MDF) and the current insufficient and unsatisfactory disposal capacities, efficient ways of recycling the waste material need to be developed. In this study, the potential of steam refining as a method to hydrolyze the resins, isolate fibers, and obtain a hemicellulose-rich extract available for further utilization in the context of a biorefinery was assessed. Two different MDF waste samples, as well as poplar (Populus spp.) and spruce (Picea spp.) wood chips for benchmarking, were treated over a severity range from 2.47 to 3.95 . The separated fiber and extract fractions were analyzed with regard to yield, content of carbohydrates, acids, degradation products, and nitrogen. A fiber fraction of more than $70 \%$ yield and an extract containing up to $30 \%$ of carbohydrates for further processing can be gained by steam-refining waste MDF. At low severities, most of the nitrogen-based compounds are solubilized. Increasing the severity leads to a decrease in nitrogen in the extract as the nitrogen compounds are converted into volatiles. A non-hydrolysable resin residue remains on the fibers, independent of the treatment severity. In comparison to the benchmark samples, the extract fraction of waste MDF shows a high $\mathrm{pH}$ of 8 and high amounts of acetic and formic acid. The generation of furfural and 5-hydroxymethylfurfural (5-HMF) on the other hand is suppressed. Distinct differences in carbohydrate hydrolysis behavior between waste MDF and conventional wood can be observed. Especially, the mannose-containing constituents seem to be resistant to hydrolysis reactions in the milieu created in MDF fractionation.
\end{abstract}

Keywords: biorefinery; MDF; recycling; waste valorization; steam treatment; hemicelluloses; fibers

\section{Introduction}

The development of engineered wood was a significant achievement for the wood-working industry, allowing previously underused low-grade wood sources to be valorized and enabling the manufacturing of wood-based materials with more uniform properties [1]. Medium-density fiberboard (MDF), a panel product made by hot-pressing refined wood fibers blended with resins, has been a tremendous success worldwide [2]. Softwood, hardwood, recycled wood, and even annual plants can be processed as raw material for MDF production [1-4]. Currently, roughly $80 \%$ of the annual production is processed for furniture or flooring applications [5]. The first commercial plant began production of MDF in 1965 in Deposit, NY, USA, under the trade name 'Baraboard' [4]. Since then, the amount of MDF manufactured globally has risen steadily, with roughly 100 million $\mathrm{m}^{3}$ produced in 2018 [6]. However, while, from a commercial point of view, the history of MDF can be considered a great success, there is still a big void in viable and commercially successful recycling methods, and a major part of the waste MDF is either burned for energy use or, if insufficient capacity is available, put into landfills [7,8]. Following the principles of the European Waste Hierarchy Directive [9], reuse and recycling methods should be given priority over energy recovery and disposal methods, as previously mentioned strategies put a huge strain on the environment through pollution of air, water, and soil [10]. 
It is estimated that $25 \%$ of the produced MDF is converted to waste in the form of off-cuts, machining errors, or transport and storage losses within one year, and 99\% of the currently produced MDF can be considered waste within 45 years. Using an average life span of 14 years, close to 50 million $\mathrm{m}^{3}$ of waste MDF was accrued worldwide in 2016 alone, with this tendency rising [8].

Taking this huge amount of lignocellulosic waste and the global endeavor to conserve natural resources into account, the urgency for viable recycling methods of this so-far untapped and ubiquitous material source becomes apparent. Biorefineries, in which all bio-based material components are valorized, are considered to play a key role in the transformation of the current fossil-based economy to a sustainable bioeconomy [11]. Waste MDF might be an economically attractive source of lignocellulosic material for such a biorefinery. In biorefineries, as a first step, the raw material is typically fractionated to render the individual components available for further processing [12,13]. Thus, a thorough understanding of the fractionation behavior of all components, including the adhesive systems, is crucial in valorization of waste MDF.

The most used adhesive system in the production of MDF is urea-formaldehyde (UF), either exclusively or fortified with a small amount of melamine. UF-resin systems with a higher amount of melamine of $12 \%$ or more are less common. Phenol formaldehyde resin (PF) and polymeric methylene diphenyl diisocyanate (PMDI) adhesive systems are used only in miniscule amounts [14]. Depending on the desired application, additives can be utilized, such as fungicides and water-repellant or fire protection agents $[2,14]$. The main advantages of UF-based adhesives are their low cost, high reactivity, and translucent color. At the same time, due to their susceptibility to hydrolysis and thus weak moisture resistance, they are considered unsuitable for outdoor use [15]. However, this susceptibility to hydrolysis can be used in the fractionation of MDF for recycling purposes. While the highest removal rate of cured resins can be achieved using acidic solutions [16], it is still possible to remove up to two-thirds of cured resin using only water at temperatures below $100{ }^{\circ} \mathrm{C}$ [17]. More intense reaction conditions, as they are found in steam treatments, can further improve the resin hydrolysis [17-20].

Pure steam treatments can be considered auto-hydrolytic processes, as water is the only reagent added [21,22]. In comparison to treatments with acid, no recovery steps are needed [23] and less corrosion-resistant material is required [24,25], leading to a comparatively low operating cost and environmental impact [26]. Steam refining, a process similar to steam explosion [27], utilizes high-pressured steam at elevated temperatures to induce auto-hydrolysis in the wood with a subsequent refining step at the end of the steam treatment to open the structure mechanically. The severity factor, introduced by Overend et al. [28], combines the reaction duration and temperature into a single parameter and can be used to describe and compare changes in the main polymers of lignocellulosic material in steam treatments.

Steam treatments of lignocellulosic material have been utilized successfully in industry [29] as a pretreatment method for enzymatic hydrolysis with subsequent microbial fermentation to gain ethanol $[27,30,31]$ or platform chemicals like succinic acid or lactic acid [32,33]. In such pretreatments for enzymatic hydrolysis, the goal is to open up the dense structure of the lignocellulosic material and increase the enzyme digestibility of the cellulose [34]. However, steam treatments can also be used to extract oligosaccharides [21,35-37]. Lately, there has been a growing interest in utilizing oligosaccharides in different applications such as biodegradable oxygen barrier films [38-40], emulsifiers [41-47], thermoplastics [48], hydrogels [49], coatings, or adhesives [50]. The remaining fibrous fraction, on the other hand, might be suitable for production of new fiberboards [51-57], cellulose nanocrystals [58,59], bioethanol [60,61], biogas, and bio-oil using pyrolysis [62,63]; however, utilization as reinforcement and filler material in wood-plastic compounds (WPCs) [64-66] and particleboards [67] has also been proposed.

Depending on the wood species and treatment conditions used, extracts of hydrothermally treated wood usually display a $\mathrm{pH}$ in the range from 3 to 5 [68-70]. Due to hydrolyzed resin compounds, the extracts of waste MDF can display a $\mathrm{pH}$ value of up to $9[20,71]$. The changed milieu is likely to influence the hydrolysis reactions of the lignocellulosic material and thus influence the properties of 
the waste MDF fractions. As these properties play a key role in the further processing and final product properties, the aim of the present study was: (i) To characterize and compare the resulting fractions of steam-refined post-consumer MDF and conventionally utilized wood species over a wide range of treatment severities by determining the content of carbohydrates, lignin, acids, and degradation products in addition to yield rate; (ii) to verify the applicability of the severity factor concept for waste MDF; (iii) to evaluate the viability of low-severity steam refining as a process to hydrolyze cured resins of post-consumer MDF by determining the nitrogen content of the fiber and extract fractions; (iv) to crosslink the abovementioned information to broaden the knowledge on the influence of the resins on the auto-hydrolytic reactions of the wood components and vice versa.

Because of their widespread availability and utilization in industry, poplar and spruce wood chips (as representatives for hard- and softwood, respectively) were evaluated in addition to two different MDF samples and compared to each other. For every material, steaming experiments with 10 differing temperature and time combinations were performed. Evaluating temperatures between 150 and $190{ }^{\circ} \mathrm{C}$ in increments of $10{ }^{\circ} \mathrm{C}$ and durations of 10 and $20 \mathrm{~min}$, a severity range from 2.47 to 3.95 was covered, and, by using different time-temperature combinations, resulting in the same severity grade, the assumed interchangeability was verified for MDF.

\section{Materials and Methods}

\subsection{Raw Materials and Their Characterization}

Both MDF charges were supplied by École supérieure du bois (Nantes, France). The first MDF charge (MDF A) consisted of off-cuts of standard panels from the in-house workshop, while the second charge (MDF B) was collected directly from an MDF producer. The MDF samples of $10 \mathrm{~mm}$ thickness were sawn into strips of $15 \mathrm{~mm}$ width and, afterward, passed through a chipper, creating chips with a length of 10 to $50 \mathrm{~mm}$. Wood chips of poplar (Populus spp.) and spruce (Picea spp.) were supplied by Lanaken Mill (Sappi, Belgium). To achieve a more homogeneous fraction for experimentation, the wood chips were screened, and fine, oversized chips and bark residuals were removed by hand. The accepted fraction of wood chips featured a thickness of no less than $8 \mathrm{~mm}$ and a length of about 20 to $30 \mathrm{~mm}$. The moisture content of the wood chips was $45-55 \%$. To prevent biological degradation, the chips were stored at $-20{ }^{\circ} \mathrm{C}$ until the day before the experiments were carried out.

The ash content was determined according to TAPPI T 211 om-16 and the elemental composition was determined using the Dumas-method with a vario EL cube (Elementar, Langenselbold, Germany). Extractive content was determined with an ASE 350 (Dionex, Sunnyvale, CA, USA) on milled (SM 2000, Retsch, Haan, Germany) material with a size of $\leq 1 \mathrm{~mm}$ diameter. The extraction was performed in three succeeding steps (petroleum ether $\left(70^{\circ} \mathrm{C}\right)$; acetone/water 9:1 $\left(70^{\circ} \mathrm{C}\right)$; water $\left(90^{\circ} \mathrm{C}\right)$ ) with a pressure of $10 \mathrm{MPa}$. The carbohydrate and lignin content determination were carried out on extracted material after acid hydrolysis and is described in detail in Section 2.4.

\subsection{Steam-Refining Treatment and Experimental Plan}

The steam refining was carried out on $300 \mathrm{~g}$ of dry material in a cylindrical $10 \mathrm{~L}$ reactor by Martin Busch \& Sohn GmbH (Schermbeck, Germany) with a diameter of $22 \mathrm{~cm}$ and a length of $25 \mathrm{~cm}$ for every experimental run. The severity factor $\left(R_{0}\right)$, combining the reaction duration ( $t$ in minutes) and temperature $\left(T\right.$ in $\left.{ }^{\circ} \mathrm{C}\right)$, was calculated according to Equation (1).

$$
\log R_{0}=t \times e^{\frac{(T-100)}{14.75}}
$$

The experiments were carried out using temperatures varying between $150{ }^{\circ} \mathrm{C}$ and $190{ }^{\circ} \mathrm{C}$ and durations of 10 and $20 \mathrm{~min}$, as summarized in Table 1 . The reactor was equipped with a four-bladed system, which was rotated at approximately $1455 \mathrm{rpm}$ by an electric motor with a power of $6.8 \mathrm{~kW}$ for $30 \mathrm{~s}$ at the end of each steaming treatment. Afterward, the steam pressure was released through a 
valve in about $90 \mathrm{~s}$. The content of the reactor was transferred into a tank by flushing with roughly $10 \mathrm{~L}$ of water. The fiber suspension was filtered through a sieve bag and the extract was separated by centrifugation in a spin-dryer (Thomas Centri 776 SEK, Thomas, Neunkirchen, Germany) for $10 \mathrm{~min}$ at $2800 \mathrm{rpm}$. The newly formed fiber fraction was homogenized for $10 \mathrm{~min}$ in a rotary stirrer with a 20 L volume (Hobart A20, Hobart, Offenburg, Germany) and the total weight was recorded. Subsequently, the fibrous material was filled into a PE-bag and stored until further evaluation at $-20^{\circ} \mathrm{C}$. The extract fraction was weighted, and the $\mathrm{pH}$ was determined with a $\mathrm{pH}-\mathrm{Meter} \mathrm{ph} 330 \mathrm{i}$ (WTW, Weilheim, Germany). Dry matter contents were determined by freeze-drying the extracts with an Alpha 2-4 LSC (Martin Christ Gefriertrocknungsanlagen GmbH, Osterode am Harz, Germany) and drying part of the fibers at $105{ }^{\circ} \mathrm{C}$ to calculate the yields based on raw material input.

Table 1. Experimental plan with reaction conditions.

\begin{tabular}{cccc}
\hline Experimental Run & Temperature & Duration & Severity \\
\hline$\#$ & ${ }^{\circ} \mathbf{C}$ & $\min$ & $\log \boldsymbol{R}_{\mathbf{0}}$ \\
\hline 1 & 150 & 10 & 2.47 \\
2 & 150 & 20 & 2.77 \\
3 & 160 & 10 & 2.77 \\
4 & 160 & 20 & 3.07 \\
5 & 170 & 10 & 3.06 \\
6 & 170 & 20 & 3.36 \\
7 & 180 & 10 & 3.36 \\
8 & 180 & 20 & 3.66 \\
9 & 190 & 10 & 3.65 \\
10 & 190 & 20 & 3.95 \\
\hline
\end{tabular}

\subsection{Acid Hydrolysis of Steam-Refined Fibers and Extract Fractions}

To determine the monomeric carbohydrate content of the fibers and the raw substrate, the material was air-dried and milled to fine powder with a T-1000 disc mill (Siebtechnik GmbH, Mülheim an der Ruhr, Germany). Subsequently, 2-stage acid hydrolysis was carried out by mixing $200 \mathrm{mg}$ of dry material with $2 \mathrm{~mL}$ of sulfuric acid (72\%, Fisher Scientific, Hampton, NH, USA) and pre-hydrolyzing at $30{ }^{\circ} \mathrm{C}$. After $60 \mathrm{~min}$, the reaction was stopped by adding $6 \mathrm{~mL}$ deionized water, and the sample was transferred with $50 \mathrm{~mL}$ deionized water into a $100 \mathrm{~mL}$ flask [72]. For the extracts, $100 \mathrm{mg}$ of lyophilized sample was dissolved in $10 \mathrm{~mL}$ water and hydrolyzed in $1.8 \mathrm{~mL} 2 \mathrm{~N} \mathrm{H}_{2} \mathrm{SO}_{4}$. Subsequently, post-hydrolysis was carried out for $40 \mathrm{~min}$ ( $30 \mathrm{~min}$ for hardwood samples) in an autoclave at $120^{\circ} \mathrm{C}$ and $0.12 \mathrm{MPa}$ on all samples to obtain monomeric sugars. Afterward, the hydrolyzed samples of the fibers and extracts were cooled and filtered on a G4 sintered glass crucible with distilled water. The acid-insoluble residue (analogous to Klason-Lignin) was dried at $105^{\circ} \mathrm{C}$ and determined gravimetrically. All samples were hydrolyzed in triplicate.

\subsection{Analytical Work}

From the hydrolyzed filtrates, the carbohydrate content was determined with a Dionex Ultimate 3000 (Dionex, Sunnyvale, CA, USA) using Borate-HPAEC as described by Lorenz et al. [72]. The acid-soluble lignin content was determined with a UV-Spectrophotometer LAMBDA 650 (PerkinElmer, Waltham, MA, USA) at a wavelength of $205 \mathrm{~nm}$ as described by Maekawa et al. [73]. Acetic and formic acids were determined from the extracts by ion chromatography, using an Ionpac AS11-HC $2 \times 250 \mathrm{~mm}$ anion exchange column (Dionex, Sunnyvale, CA, USA) conditioned at $30^{\circ} \mathrm{C}$ with $0.38 \mathrm{~mL} \mathrm{~min}^{-1}$ of $1 \mathrm{mM}$ to $70 \mathrm{mM} \mathrm{KOH}$ (Dionex, Sunnyvale, CA, USA) and detected by suppressed conductivity. Furfural and 5-hydroxymethylfurfural (5-HMF) were determined directly from the extracts after steam treatment by reverse-phase high-performance liquid chromatography (Jasco, Tokyo, Japan). An Aquasil C18 column (Thermo Scientific, Waltham, MA, USA) was used at $30^{\circ} \mathrm{C}$. A linear gradient was used, starting with $1 \mathrm{~mL} \mathrm{~min}^{-1}$ acetonitrile (Mallinckrodt Baker Bv, Deventer, 
Netherlands), ending after 80 min with 100\% 1 mM phosphoric acid (Riedel-de Haen, Seelze, Germany). Furfural (Merck, Darmstadt, Germany) and 5-HMF (Sigma Aldrich, Steinheim, Germany) were used as substance standards. A wavelength of $280 \mathrm{~nm}$ was used for UV-detection. For the measurement of the fiber length (length-weighted) and width of the fibers, a Kajaani FiberLab from Metso (Helsinki, Finland) was used on part of the fibrous material, after three passes through a laboratory refiner, using consecutively smaller gap distances of 0.05 to $0.02 \mathrm{~mm}$ and consistencies of $4 \%$ to $2 \%$.

\section{Results and Discussion}

\subsection{Raw Material Characterization}

In order to characterize the raw material extractives, the carbohydrate, lignin, and nitrogen contents were determined. In comparison to untreated wood chips of poplar and spruce, high amounts of extracts were found in MDF sample A and B, with 12.5\% and 15.8\%, respectively (see Table 2). In both samples, the highest amount of material could be found in the water extract, followed by the acetone/water extract. These findings can most likely be attributed to the presence of UF-resins, which are readily hydrolysable in water at temperatures below $100^{\circ} \mathrm{C}[16,17,74,75]$. This assumption is further strengthened by the elemental composition of the samples before and after extraction. A nitrogen content of $4.2 \%$ and $4.4 \%$ before extraction was measured in MDF A and B, respectively. Roughly two thirds of the total nitrogen of the MDF samples was removable by the accelerated solvent extraction (ASE). The high amount of nitrogen found in the MDF samples before extraction likely originates from UF-resins, as urea is composed of roughly $46.7 \%$ nitrogen. From the measured nitrogen content, assuming a molar ratio of urea to formaldehyde of 1:1, a hypothetical resin content of $13.5 \%$ for MDF A and $14.1 \%$ for MDF B can be calculated.

Table 2. Extract, carbohydrate, lignin, nitrogen, and ash contents of poplar, spruce, and medium-density fiberboard (MDF) sample A and B in [\%] based on raw material.

\begin{tabular}{|c|c|c|c|c|c|}
\hline Raw Material & & Poplar spp. & Spruce spp. & MDF A & MDF B \\
\hline \multirow{3}{*}{ Extracts } & Petroleum-ether & 0.2 & 0.3 & 0.7 & 0.9 \\
\hline & $\begin{array}{c}\text { Acetone } / \mathrm{H}_{2} \mathrm{O} \\
(9: 1)\end{array}$ & 1.6 & 0.9 & 4.8 & 4.4 \\
\hline & $\mathrm{H}_{2} \mathrm{O}$ & 1.1 & 0.6 & 7.0 & 10.5 \\
\hline \multirow{8}{*}{ Carbohydrates } & $\sum$ & 3.0 & 1.9 & 12.5 & 15.8 \\
\hline & Glucose & 48.3 & 48.3 & 38.3 & 37.6 \\
\hline & Xylose & 14.0 & 5.6 & 12.4 & 5.7 \\
\hline & Mannose & 2.7 & 12.7 & 4.0 & 7.2 \\
\hline & Galactose & 0.5 & 1.8 & 0.7 & 1.3 \\
\hline & Arabinose & 0.3 & 1.0 & 0.4 & 0.5 \\
\hline & Rhamnose & 0.3 & 0.1 & 0.2 & 0.1 \\
\hline & $\sum$ & 66.0 & 69.5 & 56.0 & 52.3 \\
\hline \multirow{3}{*}{ Residue } & Acid soluble & 2.5 & 1.2 & 2.3 & 0.9 \\
\hline & Acid insoluble & 20.0 & 25.7 & 22.1 & 24.6 \\
\hline & $\sum$ & 22.5 & 26.9 & 24.4 & 26.6 \\
\hline \multirow[t]{2}{*}{$\begin{array}{l}\text { Nitrogen } \\
\text { content }\end{array}$} & Before ASE & 0.3 & 0.3 & 4.2 & 4.4 \\
\hline & After ASE & 0.2 & 0.2 & 1.4 & 0.9 \\
\hline Ash & & 0.9 & 0.3 & 0.6 & 0.5 \\
\hline
\end{tabular}

The differences in extract content determined between sample A and B can be explained with variations in the amount of resin, the type of resin [14], and the curing degree [74]. A similar amount of nitrogen was found in standard MDF (Pfleiderer, Baruth/Mark, Germany) by Kraft [17].

Both MDF samples show a lower total carbohydrate content than the spruce and poplar sample, and comparing the two MDF samples to each other, significant differences in xylose, mannose, 
and galactose content can be observed. Sample A shows a higher xylose content with $12.4 \%$ and lower mannose and galactose content with $4.0 \%$ and $0.7 \%$ in comparison to sample B with $5.7 \%, 7.2 \%$, and $1.3 \%$, respectively. Possible reasons for these differences in carbohydrate compositions are manifold, from alterations in the raw material before MDF production through extended periods of storage in moist conditions via degradation processes induced by microbial activity or heat effects [76,77] to partial degradation of hemicelluloses in the MDF production process itself [78,79], but also, the amount of bark and compression- and tension-wood [80] can influence the carbohydrate composition. However, as all kinds of woody raw material can be used for MDF production, the differences in carbohydrate composition between MDF sample A and B most likely originate from differences in wood species used in production. In general, the hemicelluloses of hardwoods mainly consist of glucuronoxylan in combination with small amounts of glucomannan, while softwood primarily consists of galactoglucomannans and arabino-glucuronoxylans [80,81]. This is in accordance with the carbohydrate composition determined for the poplar and spruce wood chips evaluated in this study. The relative high amount of xylose in sample A suggests a high amount of hardwood included in the sample, while the high amount of mannose in Sample B suggests a larger softwood fraction in comparison to sample A. As the amount of mannose determined in sample B is still significantly less than is usually found in softwood [81], a mixture of soft- and hardwood might have been used in the production of MDF sample B. However, for all the above-mentioned reasons, it is impossible to calculate the exact hardwood/softwood ratios for the samples.

\subsection{Effect of Severity on the Yield of Waste MDF in Comparison to Poplar and Spruce Wood}

The yield after fractionation is an important parameter for evaluating the process reactions and the economic implication. In the evaluated severity range, the fiber yield of all materials decreases with increasing severity (Figure 1a-d, complete data in Table A1). For poplar and spruce wood, a fiber yield of roughly $96 \%$ is calculated at a severity of 2.47 , and $77.4 \%$ and $72.6 \%$, respectively, at a severity of 3.95 . At the same time, the extract yield increases from 3.3\% for poplar and $1.9 \%$ for spruce at a severity of 2.47 to $18.1 \%$ and $19.6 \%$ at a severity of 3.95 (Figure $1 \mathrm{a}, \mathrm{b}$ ), as hemicelluloses progressively solubilize [21,82]. For poplar wood, a maximum extract yield of $21.4 \%$ at a severity of 4.53 was determined by Schütt et al. [83]. At even higher severities, the amount of extract decreases again, as degradation reactions of the mono- and polymers into volatile compounds increase. Thus, the maximum extract yield can be gained at a severity in which the amount of material solubilized is in equilibrium with the amount of mono- and polymers transformed into volatiles by degradation reactions.

In contrast to the benchmarking samples, MDF sample A and B show a much lower fiber yield with $85.3 \%$ and $82.0 \%$ and a higher extract yield of $12.1 \%$ and $18.4 \%$, respectively, at a severity of 2.47 (Figure 1c,d). This matches with the finding of the accelerated solvent extraction performed for raw material characterization, in which a high amount of material was found to be extractable at temperatures below $100{ }^{\circ} \mathrm{C}$. Adding the calculated amount of resins to the fiber yield leads to an adjusted fiber yield of $98.8 \%$ and $96.1 \%$ for MDF A and B, respectively, which is in line with the fiber yield of native wood. Thus, the high amount of extract and low amount of fiber yield at low severities, in comparison to the native spruce and poplar wood, mainly results from the resins in the MDF samples.

At a severity of 3.95 , all samples reach a similar value of $18 \%$ to $20 \%$ extract yield and $72 \%$ to $78 \%$ of fiber yield. The decrease in fiber yield from a severity of 2.47 to 3.95 is lower in the MDF samples than in the native wood samples. As the amount of resin found on the fibers seems to be independent of the treatment severity, this is unlikely to be explainable by changes in the resin residue, but might be due to a deceleration of hydrolysis reactions of the main polymers. This aspect is discussed in detail in Section 3.4. The extract yield of MDF sample B (Figure 1d) seems to be independent of the severity grade. One possible explanation is that the resin degradation in the extract is in equilibrium with the carbohydrate solubilization from the wood material, leading to changes in the composition of the extract but keeping the quantity constant. 


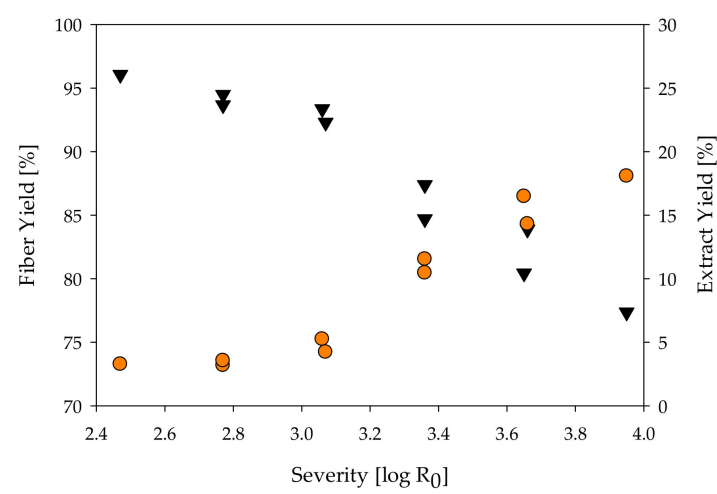

(a)

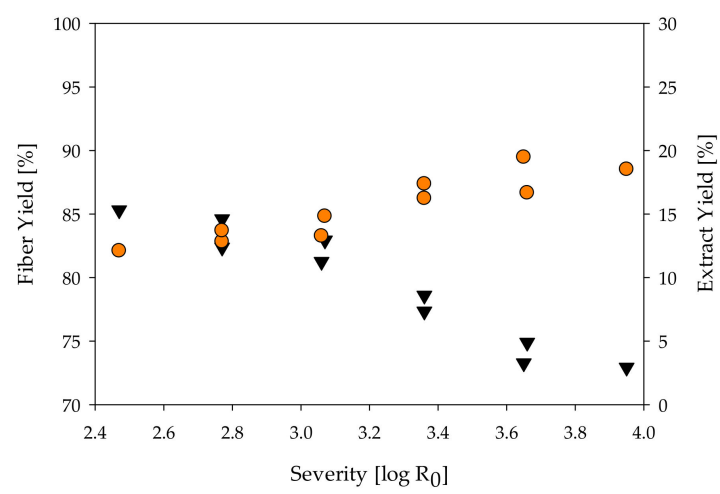

(c)

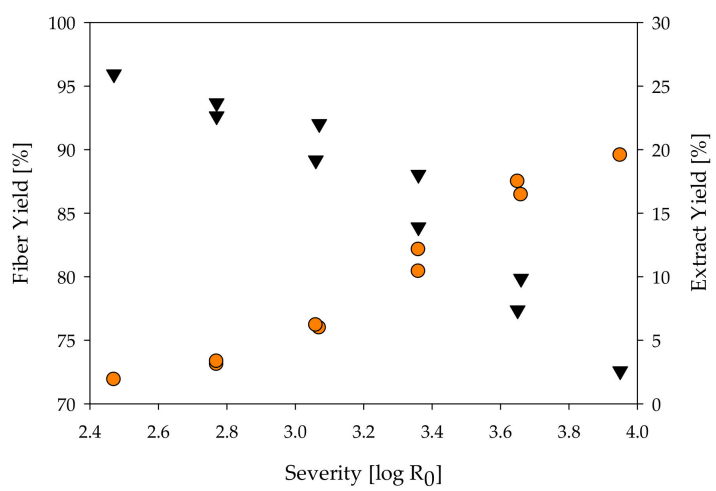

(b)

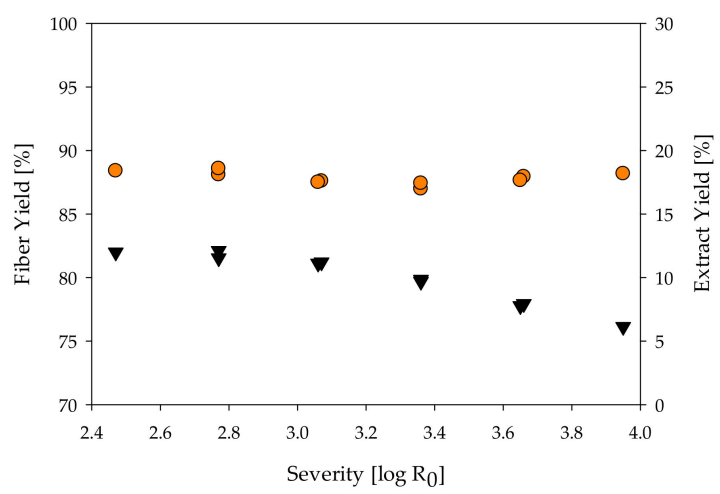

(d)

Fiber fraction $\bigcirc$ Extract fraction

Figure 1. Influence of severity on yield of extract and fiber fraction of (a) poplar; (b) spruce; (c) MDF Sample A; (d) MDF Sample B.

\subsection{Influence of the Treatment Severity on the Presence of Nitrogen Compounds in the Fractions of Waste MDF}

The behavior of the resins in steaming treatments is of special interest, as two concurrent hydrolysis reactions are happening in the steam treatment of MDF: The hydrolysis of the resins and the hydrolysis of the wood polymers. It can be expected that the resins and their hydrolysis products influence the hydrolysis reactions of the lignocellulosic material and vice versa.

UF-resin polymers are hydrolytically degradable into smaller fragments by cleavage of methylene (Figure 2a) and methylene-ether (Figure 2b) bridges. The resulting terminal hydroxymethyl groups (Figure 2a,b) can undergo dissociation into formaldehyde and urea derivates. Another possible degradation mechanism is by separation of an amine and formation of an intermediate carbamic acid (Figure 2c) [19]. As nitrogen is the main component of UF-resins, it can be measured for quantitative analysis of resin hydrolysis. The nitrogen content of the separate fiber and extract fractions was measured by elemental analyses and put into relation with the corresponding yields and the total nitrogen content found in the raw material to create mass balances (Figure 3). The difference between the total nitrogen content of the raw material and nitrogen found in the extract and fibers combined is assumed to be volatile and transformed into the gaseous phase. From $70 \%$ to $80 \%$ of the total resin is solubilized at the lowest severity assessed in this study, and roughly $20 \%$ of the nitrogen remains on the fibers, independent of the treatment severity. 
(a)
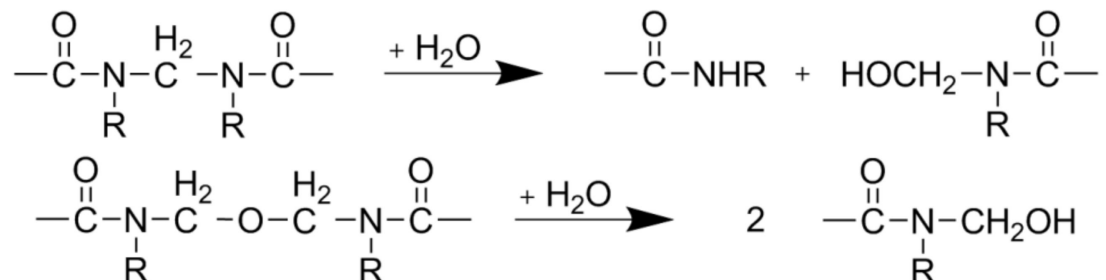

(c)<smiles>CCN(C)C(N)=O</smiles><smiles>COCCON</smiles><smiles>C[CH]N(C)C(=O)O</smiles>

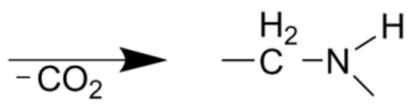

Figure 2. Degradation pathways of urea-formaldehyde (UF)-resin polymers: Cleavage of (a) methylene or (b) methylene-ether bridges and (c) separation of an amine [19].

For both MDF samples, the amount of nitrogen in the extract decreases as the severity rises, while the amount of nitrogen assumed to be in the gaseous phase rises. Using less intense reaction conditions than examined in this study leads to an increasing rate of solubilization of nitrogen compounds, and an ensuing decrease in nitrogen found on fibers can be observed [75]. However, as no change in nitrogen content of the fiber fraction can be observed in this study, the remaining $20 \%$ of nitrogen compounds found on the fibers in this study seem to be comparatively resistant to hydrolysis. To evaluate if the nitrogen compounds on the fibers can be easily removed, the nitrogen content of the sample treated at a severity of 3.95 was measured again after the additional refining step, which includes a very effective washing protocol. However, no substantial difference in nitrogen content could be determined. Thus, besides being highly resistant to hydrolysis, the remaining nitrogen compounds in the fiber fraction cannot be removed mechanically and are likely chemically linked to the fibers. By increasing the severity of the treatment, the nitrogen compounds found in the extract, on the other hand, seem to increasingly degrade to volatile products, which pass over from the extract into the gas phase.

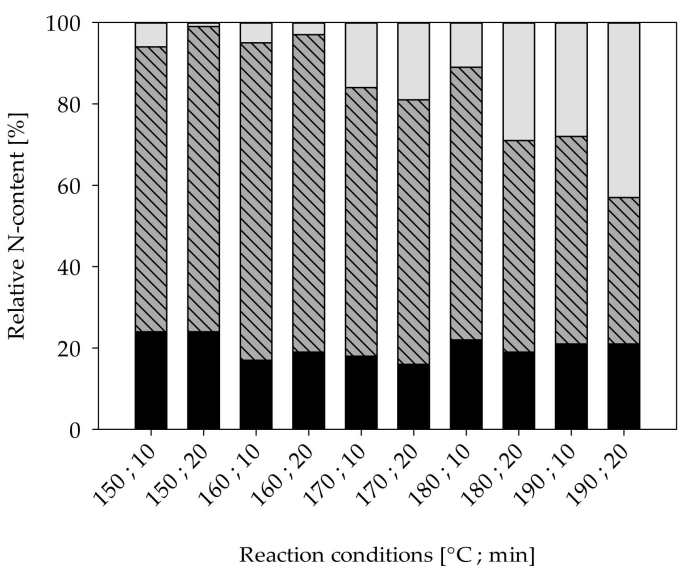

(a)

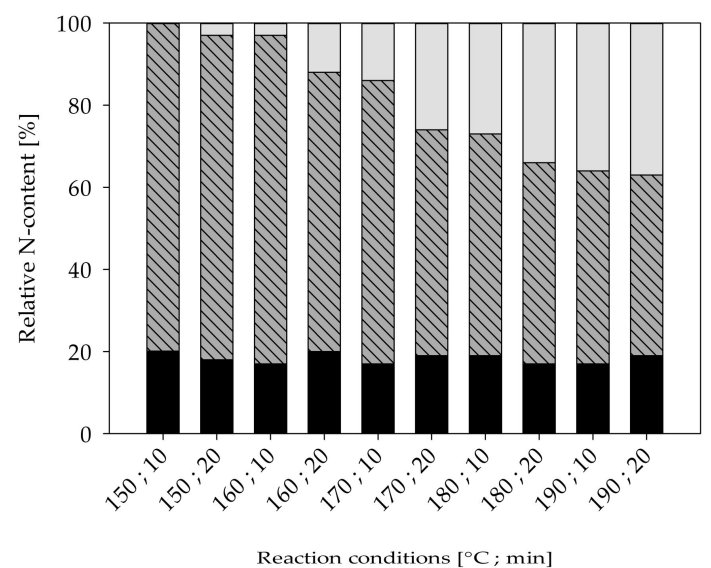

(b)

Fibrous fraction IIV Extract fraction

$\square$ Gaseous fraction (calculated as difference between N-content of fiber and extract fraction and the raw material)

Figure 3. Distribution of total nitrogen content in the fiber, extract, and gaseous fraction (calculated as difference between nitrogen content of fiber and extraction fraction and raw material) of MDF sample A (a) and MDF sample B (b).

Additionally, the resin hydrolysis behavior reported in this study shows distinct differences to the hydrolysis behavior of pure, cured UF resins. In experiments done by Grigsby et al. [74], almost no change in nitrogen content could be observed in pure acid-cured UF resins extracted with water at $60^{\circ} \mathrm{C}$ over $24 \mathrm{~h}$. In the MDF samples used in this study, on the other hand, a high amount of material, of which nitrogen is a big part, could be extracted using water at $90^{\circ} \mathrm{C}$ (Table 2). In experiments 
conducted by Fleischer and Marutzky [19], pure UF resin steamed for $50 \mathrm{~min}$ at $130{ }^{\circ} \mathrm{C}$ released only $14 \%$ of the material's total formaldehyde, while UF-resin-bonded particleboards steamed under the same conditions released up to $70 \%$ of the total formaldehyde. A comparable amount of formaldehyde release was determined by Kraft and Roffael [75] using similar treatment conditions on MDF samples. As the formaldehyde release can be used as an indicator for the resin hydrolysis, the much lower formaldehyde release of the pure UF resins indicates a high hydrolysis resistance in comparison to UF resins blended with fibers. One possible reason for this might be the fine distribution of the resin among the fibers in production and its impact on the curing degree of the resin [74]. Interactions between acids released from the fibers, resin, and hardeners might also influence the curing and degradation of the resins.

\subsection{Influence of the Severity on the Hydrolysis Reactions of the Wood Polymers}

During the treatment, steam penetrates and condenses inside the microporous structures of the lignocellulosic material. In general, at high temperatures, the condensed water dissociates and creates an acidic milieu [84]. The hydronium ion concentration starts to rise as acetyl groups are cleaved from hemicelluloses by acid-catalyzed hydrolysis, further increasing the reaction rate [85]. As a function of temperature and $\mathrm{pH}$, ester and ether bonds are cleaved and, consequently, carbohydrates are depolymerized and start solubilizing [82]. Concurrently, volatile degradation products like furfural from pentoses and 5-HMF from hexoses are formed [81]. Thus, to characterize the steam-refined fractions in detail and assess the hydrolysis reactions, the content of carbohydrates and acid-insoluble residue (AIR) was determined for the fiber and extract fractions for all samples (Table 3). Additionally, the extracts were examined in regard to $\mathrm{pH}$, acetic and formic acid (Figure 4), and degradation products such as furfural and 5-HMF (Figure 5). All contents are calculated based on raw material.

For all samples, a decrease in the amount of glucose in the fiber fraction with increasing severity can be observed. Concurrently, the amount of glucose in the extract increases slightly. These effects are less pronounced in MDF sample A and B. Glucose, besides being the main constituent of cellulose, also occurs as a component in hemicelluloses in different amounts, depending on plant species, development stage, and cell wall type [86]. As cellulose is resistant to hydrolysis in hydrothermal treatments at temperatures below $200{ }^{\circ} \mathrm{C}$ [82], the liberated glucose likely originates mainly from hemicelluloses. An increase in treatment severity also leads to a reduction in xylose content in the fiber fraction and an increase in the extract fraction for all samples, as the solubilization of the xylose increases. The same can be observed for mannans in poplar and spruce wood. In contrast to that, the mannose content in the fiber and extract fraction of the MDF samples shows almost no changes. This reduced degradation of mannose-containing polysaccharides (glucomannans and galactoglucomannans) might be due to differences in $\mathrm{pH}$ and acid content (see Figure 4). This could be an explanation for the differing yield behavior of MDF sample B (Figure 1d), which has comparatively high mannose content, and the reduced removal of glucose from the fiber fraction in MDF samples mentioned before. The amount of glucose, xylose, and mannose found in the extract is less than the corresponding amount of monomers missing in the fiber fraction likely due to degradation. A slight increase in total AIR (sum of extract and fiber fraction AIR) can be observed with increasing severity. The highest total AIR for the poplar, MDF A, and MDF B sample is found at the highest severity of 3.95 with a total AIR of $25.8 \%, 24.9 \%$, and $29.3 \%$, respectively. For spruce, the highest AIR is found at treatment conditions of $170{ }^{\circ} \mathrm{C}$ and $20 \mathrm{~min}$ with $29.7 \%$. In comparison to the AIR of the corresponding raw material, this translates to an increase between $2.8 \%$ to $5.8 \%$. This increase can be explained with the formation of pseudo-lignin from degradation products of carbohydrates [87-89]. 
Table 3. Carbohydrates and lignin content in the fiber and extract fraction (in \% based on raw material).

\begin{tabular}{|c|c|c|c|c|c|c|c|c|c|c|c|c|}
\hline & \multirow[b]{2}{*}{$\underset{\#}{\text { Run }}$} & \multirow[b]{2}{*}{$\begin{array}{c}\text { Severity } \\
\log R_{0}\end{array}$} & \multicolumn{5}{|c|}{ Fiber Fraction } & \multicolumn{5}{|c|}{ Extract Fraction } \\
\hline & & & $\begin{array}{l}\text { Glc } \\
{[\%]}\end{array}$ & $\begin{array}{l}\text { Xyl } \\
{[\%]}\end{array}$ & $\begin{array}{c}\text { Man } \\
{[\%]}\end{array}$ & $\begin{array}{l}\mathrm{OC}^{*} \\
{[\%]}\end{array}$ & $\begin{array}{l}\text { AIR } \\
{[\%]}\end{array}$ & $\begin{array}{l}\text { Glc } \\
{[\%]}\end{array}$ & $\begin{array}{l}\mathrm{Xyl} \\
{[\%]}\end{array}$ & $\begin{array}{c}\text { Man } \\
{[\%]}\end{array}$ & $\begin{array}{l}\mathrm{OC}^{*} \\
{[\%]}\end{array}$ & $\begin{array}{l}\text { AIR } \\
{[\%]}\end{array}$ \\
\hline \multirow[t]{10}{*}{ Poplar } & 1 & 2.47 & 48.2 & 14.0 & 2.3 & 1.0 & 23.8 & 0.1 & 0.1 & 0.2 & 0.2 & 0.6 \\
\hline & 2 & 2.77 & 47.4 & 13.3 & 2.2 & 0.8 & 23.5 & 0.1 & 0.1 & 0.2 & 0.2 & 0.8 \\
\hline & 3 & 2.77 & 47.1 & 13.4 & 2.3 & 0.9 & 23.3 & 0.1 & 0.1 & 0.2 & 0.3 & 0.7 \\
\hline & 4 & 3.07 & 47.0 & 13.2 & 2.2 & 0.8 & 22.8 & 0.1 & 0.4 & 0.3 & 0.4 & 0.6 \\
\hline & 5 & 3.06 & 48.0 & 13.0 & 2.1 & 0.8 & 23.6 & 0.1 & 0.8 & 0.4 & 0.5 & 0.8 \\
\hline & 6 & 3.36 & 46.7 & 9.1 & 2.0 & 0.4 & 23.7 & 0.3 & 4.5 & 0.5 & 0.7 & 1.1 \\
\hline & 7 & 3.36 & 49.1 & 9.4 & 1.8 & 0.5 & 23.1 & 0.3 & 3.4 & 0.5 & 0.7 & 1.0 \\
\hline & 8 & 3.66 & 47.1 & 7.9 & 1.8 & 0.3 & 24.2 & 0.3 & 6.2 & 0.7 & 0.8 & 1.0 \\
\hline & 9 & 3.65 & 46.4 & 6.3 & 1.6 & 0.3 & 24.1 & 0.3 & 7.3 & 1.0 & 0.8 & 0.9 \\
\hline & 10 & 3.95 & 46.5 & 4.1 & 1.3 & 0.1 & 24.5 & 0.3 & 7.6 & 1.0 & 0.8 & 1.3 \\
\hline \multirow[t]{10}{*}{ Spruce } & 1 & 2.47 & 44.2 & 4.8 & 11.7 & 2.3 & 29.1 & 0.2 & 0.0 & 0.3 & 0.4 & 0.3 \\
\hline & 2 & 2.77 & 43.9 & 4.7 & 11.2 & 1.9 & 27.9 & 0.2 & 0.1 & 0.6 & 0.7 & 0.5 \\
\hline & 3 & 2.77 & 43.8 & 4.6 & 10.9 & 1.8 & 27.7 & 0.2 & 0.1 & 0.8 & 0.7 & 0.4 \\
\hline & 4 & 3.07 & 45.0 & 4.7 & 10.7 & 1.7 & 28.3 & 0.3 & 0.3 & 1.5 & 1.1 & 0.3 \\
\hline & 5 & 3.06 & 41.1 & 4.2 & 9.5 & 1.4 & 28.6 & 0.4 & 0.5 & 2.0 & 1.1 & 0.3 \\
\hline & 6 & 3.36 & 42.7 & 4.0 & 7.4 & 1.1 & 29.3 & 0.6 & 1.0 & 3.5 & 1.4 & 0.4 \\
\hline & 7 & 3.36 & 42.9 & 3.7 & 7.0 & 0.8 & 27.6 & 0.7 & 1.3 & 4.6 & 1.5 & 0.1 \\
\hline & 8 & 3.66 & 40.0 & 3.0 & 4.8 & 0.5 & 28.4 & 1.1 & 1.9 & 6.5 & 1.8 & 0.4 \\
\hline & 9 & 3.65 & 40.2 & 2.6 & 4.3 & 0.4 & 27.5 & 0.9 & 2.0 & 6.8 & 1.7 & 1.0 \\
\hline & 10 & 3.95 & 41.6 & 2.3 & 2.9 & 0.2 & 26.5 & 1.0 & 2.1 & 8.2 & 1.7 & 0.9 \\
\hline \multirow[t]{10}{*}{ MDF A } & 1 & 2.47 & 36.1 & 11.9 & 3.7 & 1.1 & 23.2 & 0.2 & 0.4 & 0.3 & 0.4 & 0.7 \\
\hline & 2 & 2.77 & 36.1 & 11.8 & 3.6 & 1.0 & 22.4 & 0.2 & 0.5 & 0.3 & 0.4 & 0.8 \\
\hline & 3 & 2.77 & 35.7 & 11.5 & 3.6 & 0.9 & 21.0 & 0.2 & 0.7 & 0.3 & 0.4 & 1.7 \\
\hline & 4 & 3.07 & 35.6 & 10.9 & 3.7 & 0.9 & 22.0 & 0.3 & 1.0 & 0.3 & 0.5 & 1.1 \\
\hline & 5 & 3.06 & 35.4 & 10.7 & 3.9 & 0.8 & 22.5 & 0.2 & 1.0 & 0.2 & 0.4 & 1.6 \\
\hline & 6 & 3.36 & 34.2 & 9.8 & 3.3 & 0.6 & 21.0 & 0.3 & 2.6 & 0.2 & 0.5 & 2.6 \\
\hline & 7 & 3.36 & 33.4 & 9.6 & 3.5 & 0.7 & 22.8 & 0.3 & 2.2 & 0.2 & 0.5 & 1.0 \\
\hline & 8 & 3.66 & 34.1 & 8.0 & 3.5 & 0.6 & 22.4 & 0.3 & 3.8 & 0.1 & 0.5 & 2.1 \\
\hline & 9 & 3.65 & 35.5 & 7.5 & 3.4 & 0.5 & 21.7 & 0.3 & 4.3 & 0.1 & 0.5 & 2.2 \\
\hline & 10 & 3.95 & 35.2 & 5.8 & 3.4 & 0.4 & 24.0 & 0.3 & 4.7 & 0.2 & 0.5 & 0.9 \\
\hline \multirow[t]{10}{*}{ MDF B } & 1 & 2.47 & 38.3 & 5.7 & 7.0 & 1.8 & 25.9 & 0.6 & 0.5 & 1.1 & 1.0 & 2.1 \\
\hline & 2 & 2.77 & 38.4 & 5.6 & 6.9 & 1.7 & 26.4 & 0.6 & 0.6 & 1.2 & 0.9 & 1.8 \\
\hline & 3 & 2.77 & 38.0 & 5.4 & 6.8 & 1.8 & 26.2 & 0.6 & 0.7 & 1.2 & 0.9 & 2.0 \\
\hline & 4 & 3.07 & 37.8 & 5.3 & 6.8 & 1.7 & 26.9 & 0.6 & 0.9 & 1.1 & 0.9 & 2.0 \\
\hline & 5 & 3.06 & 37.9 & 5.2 & 6.7 & 1.5 & 26.6 & 0.6 & 0.9 & 1.2 & 0.9 & 2.0 \\
\hline & 6 & 3.36 & 38.6 & 4.9 & 6.9 & 1.7 & 25.9 & 0.6 & 1.3 & 1.0 & 0.9 & 2.1 \\
\hline & 7 & 3.36 & 39.3 & 4.8 & 6.9 & 1.6 & 26.3 & 0.6 & 1.4 & 1.1 & 0.9 & 2.1 \\
\hline & 8 & 3.66 & 39.3 & 4.3 & 6.9 & 1.6 & 26.2 & 0.6 & 1.9 & 1.1 & 0.9 & 2.3 \\
\hline & 9 & 3.65 & 37.9 & 4.0 & 6.5 & 1.5 & 27.0 & 0.6 & 2.0 & 1.1 & 0.9 & 2.1 \\
\hline & 10 & 3.95 & 37.7 & 3.3 & 6.2 & 1.3 & 26.9 & 0.6 & 2.3 & 1.2 & 0.9 & 2.4 \\
\hline
\end{tabular}

* Other carbohydrates (arabinose, rhamnose, galactose).

Comparing the $\mathrm{pH}$ of the extracts, distinct differences between MDF and pure wood samples can be observed. The $\mathrm{pH}$ of the poplar extracts decreases from 6.9 to 4.4 , while the $\mathrm{pH}$ of the spruce extracts stays around 5 in the examined severity range. In general, an acidic milieu is to be expected, as acetic acid is freed from acetyl groups of the wood in hot and humid conditions like they are found in steam treatments $[85,90]$. In the extracts of waste MDF, on the other hand, the $\mathrm{pH}$ rises from 7.6 for MDF A and 7.4 for MDF B at the lowest severity of 2.47 to approximately 8 at higher severities. The high $\mathrm{pH}$ of the MDF samples likely originates from ammonium hydroxide, which is converted from ammonia in watery solutions. The ammonia, in turn, is hydrolytically cleaved from the UF-resin polymers $[18,19]$. For all samples, the amount of formic and acetic acid rises with increasing severity. Despite the lower $\mathrm{pH}$ of the wood samples, the amount of formic and acetic acid found is less than those in the MDF extracts. The high acid content in the MDF extracts might be due to reactions of the wood polymers with mineral acids $\left(\mathrm{H}_{2} \mathrm{SO}_{4}\right)$ released from hardeners $\left(\left(\mathrm{NH}_{4}\right)_{2} \mathrm{SO}_{4}\right)$ used in MDF 
production [20]. Especially in MDF sample A, high amounts of acids can be observed, which could be due to the postulated high amount of hardwood used in the production of MDF sample A and its inherent, in comparison to softwood, high amount of acetyl groups.

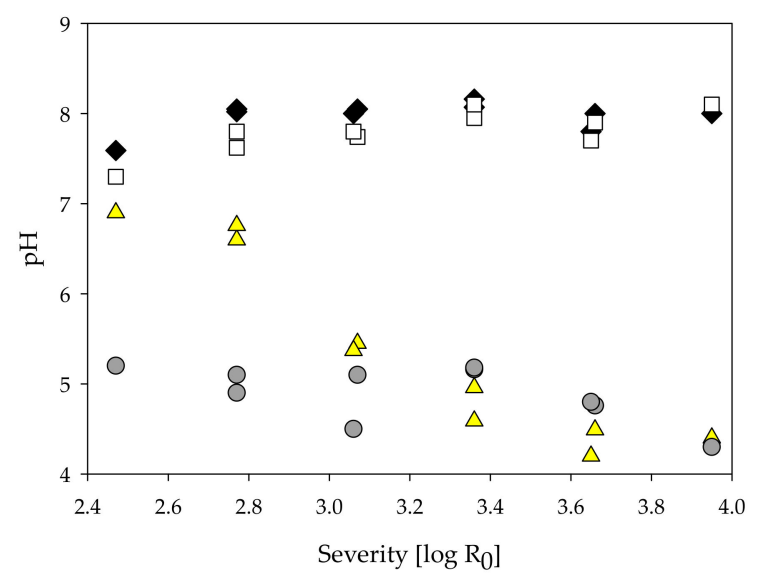

(a)

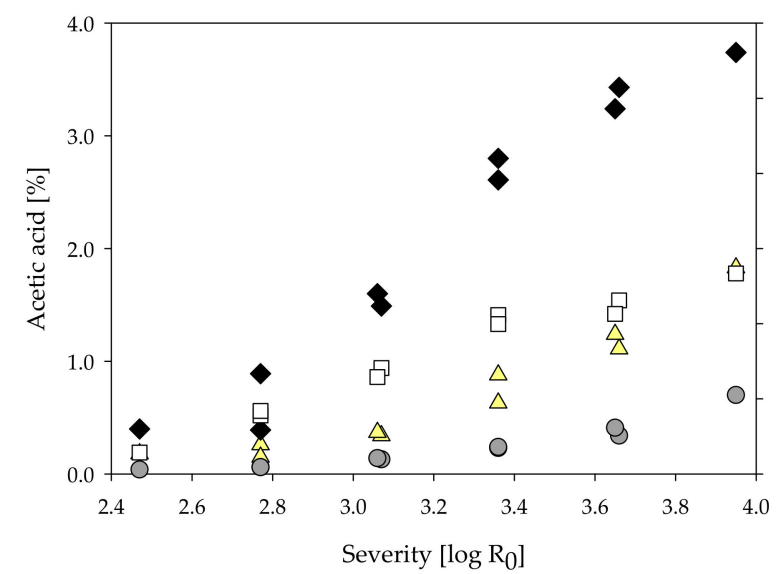

(b)

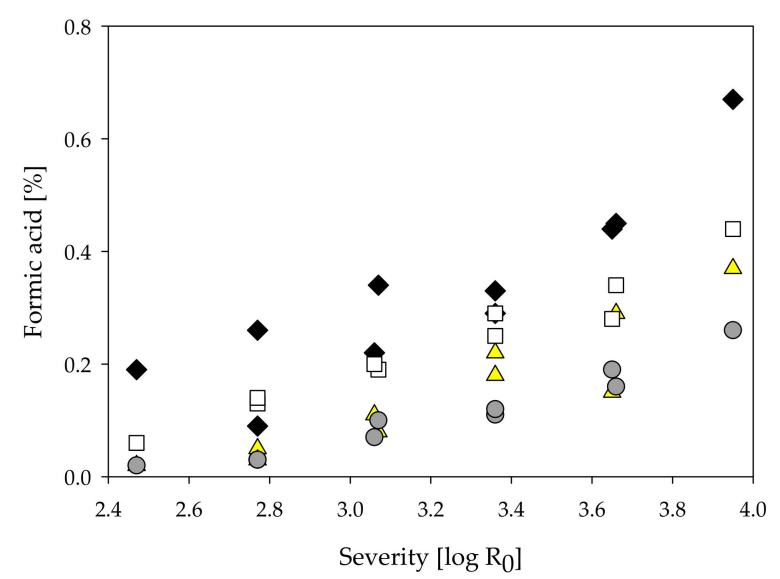

(c)

$\triangle$ Poplar $\bigcirc$ Spruce $\bullet$ MDF A $\square \quad$ MDF B

Figure 4. Influence of treatment severity on $\mathrm{pH}(\mathbf{a})$, and acetic acid (b) and formic acid (c) contents of steam-refining extracts of poplar, spruce, and the MDF samples.

Furfural and 5-HMF are compounds resulting from degradation processes of pentoses and hexoses, respectively, under acidic conditions [91,92]. The furfural and 5-HMF content increases with the 
treatment severity for poplar and spruce wood (Figure 5). By comparison, no degradation products could be found in the MDF samples. Only at the highest severity of 3.95 and only in MDF sample $\mathrm{B}$, a slight rise in amount of degradation products could be observed. Even though the low amount of degradation products might be due to further degradation to formic acid, it is more likely that 5-HMF and furfural are not formed at all during the steam treatment of the MDF samples, as all the aforementioned degradation processes are reported to happen in acidic conditions and are non-existent in alkaline treatments [82].

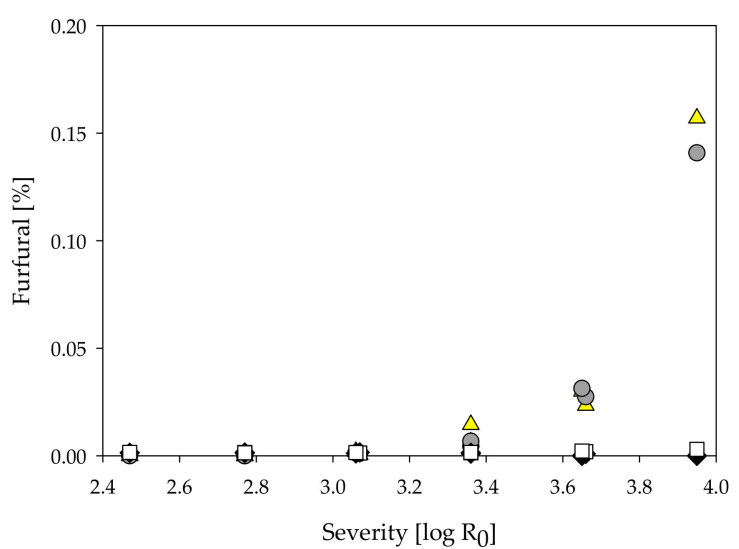

(a)

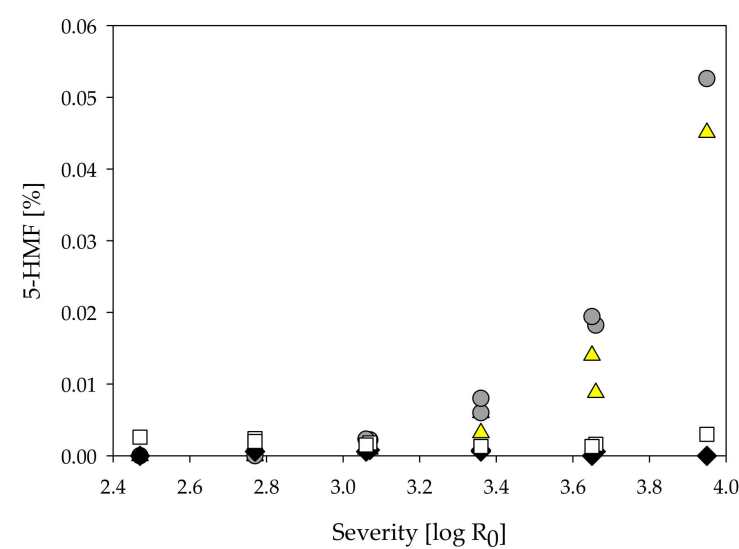

(b)

$\triangle$ Poplar $\bigcirc$ Spruce $\bullet$ MDF A $\quad$ MDF B

Figure 5. Influence of treatment severity on furfural (a) and 5-hydroxymethylfurfural (5-HMF) (b) content of steam-refining extracts of poplar, spruce, and the MDF samples.

\subsection{Observations on Morphological Changes of the Fibrous Material}

Because of the intense mechanical forces applied to the MDF and native wood samples in steam refining, changes in the fiber morphology can be expected in addition to the addressed chemical changes. Before the treatment, the sample materials are present as chips, as described in Section 2.1. After a steam-refining treatment at a low severity of 2.47, whole pieces of wood chips can still be found in the fibrous material of the native wood sample (Figures 6a and 7a). At a severity of 3.06, the wood chips are smaller and frayed (Figures $6 b$ and $7 b$ ). At higher severities of 3.36 and more, most of the fibrous material is present in small fiber strands and bundles (Figure $6 c, d$ and Figure $7 c, d$ ). This is likely due to the lignin softening at the temperature of $165^{\circ} \mathrm{C}$ [93], enabling an easier separation of the fibrils at higher severities.

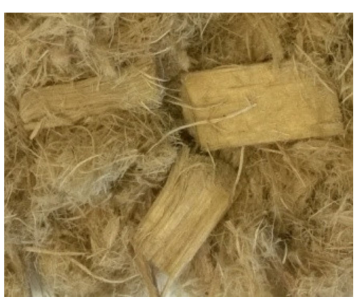

(a)

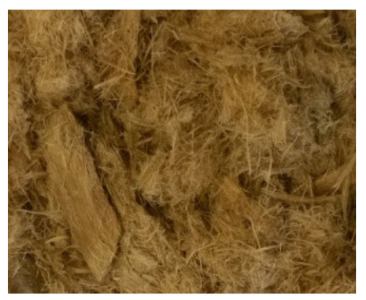

(b)

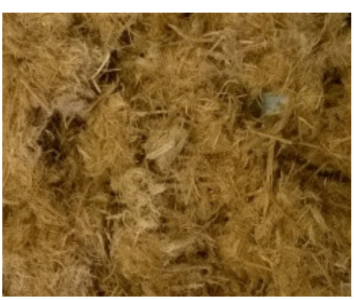

(c)

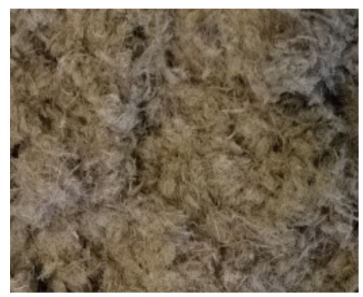

(d)

Figure 6. Morphology of poplar wood after steam refining using different treatment conditions $\left[\log R_{0}\right.$; ${ }^{\circ} \mathrm{C}$; min]: (a) 2.47; 150; 10, (b) 3.06; 160; 20, (c) 3.36; 180; 10, (d) 3.95; 190; 20. 


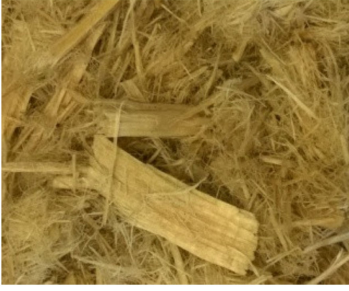

(a)

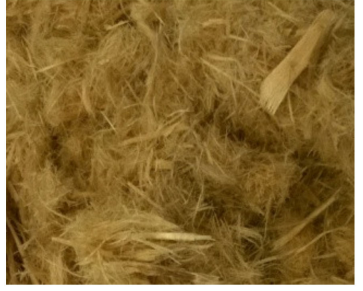

(b)

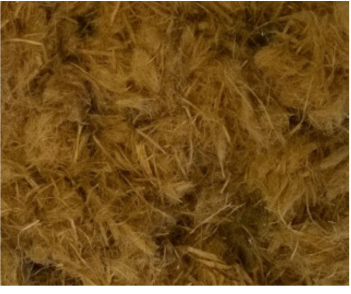

(c)

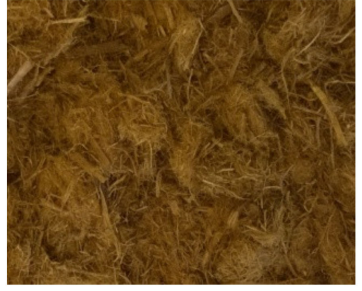

(d)

Figure 7. Morphology of spruce wood after steam refining using different treatment conditions $\left[\log R_{0}\right.$; ${ }^{\circ} \mathrm{C}$; min]: (a) 2.47; 150; 10, (b) 3.06; 160; 20, (c) 3.36; 180; 10, (d) 3.95; 190; 20.

The fibers of MDF sample A, on the other hand, are largely separated, independent of treatment severity (Figure 8a-d). MDF sample B (not pictured) shows the same morphology pattern as MDF sample A. Even in steam-refining treatments conducted at the lowest severity grade of 2.47, only small fiber bundles are visible (Figure 8a). This is likely due to fibers already having been separated in the MDF production process and the resin holding the fibers together being dissolved even at the lowest examined severity grade. No distinct changes in the amount or size of the small fiber bundles can be observed at higher severity treatments (Figure $8 b-d$ ). Thus, the fibrous fractions remaining in the form of small fiber bundles for all materials are likely due to the fiber bundles being too small for the refining gap in the steam-refining reactor.

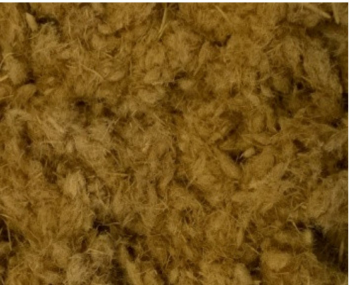

(a)

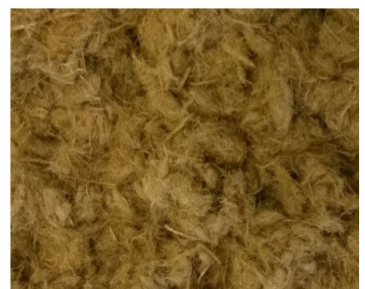

(b)

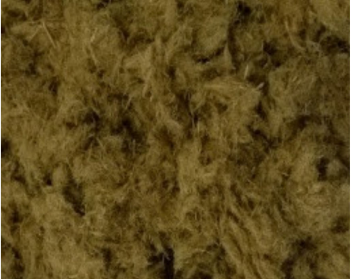

(c)

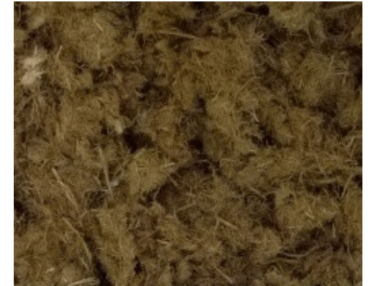

(d)

Figure 8. Morphology of MDF sample A after steam refining using different treatment conditions $\left[\log R_{0} ;{ }^{\circ} \mathrm{C} ; \min \right]:$ (a) 2.47; 150; 10, (b) 3.06; 160; 20, (c) 3.36; 180; 10, (d) 3.95; 190; 20.

An additional mild refiner treatment at low energy input was performed for all samples in order to achieve a complete fiber separation (see Section 2.4). In Table 4, the measured fiber lengths and widths for selected materials are presented and compared to recycled pulp from an industrial corrugated cardboard producer.

Table 4. Fiber length and diameter of steam-treated poplar, spruce, MDF A, MDF B, and recycled pulp.

\begin{tabular}{cccccc}
\hline Sample & $\begin{array}{c}\text { Severity } \\
{\left[\log \boldsymbol{R}_{\mathbf{0}}\right]}\end{array}$ & $\begin{array}{c}\text { Temperature } \\
{\left[{ }^{\circ} \mathbf{C}\right]}\end{array}$ & $\begin{array}{c}\text { Duration } \\
{[\mathbf{m i n}]}\end{array}$ & $\begin{array}{c}\text { Fiber Length } \\
{[\mathbf{m m}]}\end{array}$ & $\begin{array}{c}\text { Diameter } \\
{[\boldsymbol{\mu m}]}\end{array}$ \\
\hline Poplar & 2.47 & 150 & 10 & 0.68 & 25.6 \\
Poplar & 3.36 & 170 & 20 & 0.87 & 24.4 \\
Poplar & 3.95 & 190 & 20 & 0.80 & 22.7 \\
Spruce & 2.47 & 150 & 10 & 0.90 & 28.3 \\
Spruce & 3.36 & 170 & 20 & 0.97 & 28.6 \\
Spruce & 3.95 & 190 & 20 & 0.89 & 28.5 \\
MDF A & 2.47 & 150 & 10 & 0.82 & 25.0 \\
MDF A & 3.36 & 170 & 20 & 0.86 & 25.5 \\
MDF A & 3.95 & 190 & 20 & 0.79 & 24.3 \\
MDF B & 2.47 & 150 & 10 & 1.02 & 30.3 \\
MDF B & 3.36 & 170 & 20 & 0.95 & 29.9 \\
MDF B & 3.95 & 190 & 20 & 0.95 & 29.4 \\
Recycled pulp & - & - & - & 1.09 & 22.1 \\
\hline
\end{tabular}


By comparing the same raw materials treated at different severities, no clear changes in fiber length and width can be observed. The only exception is the poplar sample treated at $150{ }^{\circ} \mathrm{C}$ and $10 \mathrm{~min}$, displaying a distinctively lower average fiber length. This might be due to an increase in number of small fibers, as the fiber sample included almost intact wood chips after steam refining. The insufficient softening of the structure might lead to increased rupture of the fibers in the refiner and a higher amount of small fibers in comparison to the poplar samples treated at higher severities.

However, distinct differences between the different samples dependent on the raw material can be observed. As stated in the literature, with a fiber length of 1.7 to $4.6 \mathrm{~mm}$, untreated spruce fibers (Picea abies) are longer than untreated poplar fibers (Populus spp.) with fiber lengths from 0.6 to $1.6 \mathrm{~mm}$ [81]. After the steam and refining treatment, the spruce fibers with average lengths of 0.89 to $0.97 \mathrm{~mm}$ are still longer than the poplar fibers with average fiber lengths of 0.68 to $0.87 \mathrm{~mm}$. However, as the size reduction is much greater for the spruce fibers, the average fiber lengths converge. In MDF sample $\mathrm{A}$, with measured average fiber lengths of 0.79 to $0.86 \mathrm{~mm}$, the fibers are shorter than those in MDF sample $B$, with average fiber lengths ranging from 0.95 to $1.02 \mathrm{~mm}$. In addition, the fibers from MDF A show smaller average widths of roughly $25 \mathrm{~mm}$ in comparison to the fibers from MDF sample B with average widths of 29.4 to $30.3 \mathrm{~mm}$. Thus, the widths of MDF sample A are closer to the widths of the poplar samples, while the widths of MDF sample B are close to the widths of the spruce samples. These results support the assumption of a higher softwood content in MDF sample B, as fibers from softwoods usually have larger dimensions than fibers from hardwoods. Surprisingly, the spruce fibers are shorter than the fibers of MDF sample B. This could be due to the lignocellulosic material used in the production of MDF sample B, which might have included softwood with even longer fibers. Another possible explanation is, as the fibers have been separated before in the MDF production process, the MDF fibers experience less mechanical forces in the refining, leading to longer fibers. As the fibers from MDF B are close to the fiber length of the recycled pulp for packaging applications, they might be acceptable as an added reinforcement fiber in such applications.

\section{Conclusions}

With steam refining, it is possible to gain an extract containing up to $30 \%$ of carbohydrates while still retaining a high yield fiber fraction for further conversion from post-consumer MDF. As the fibers are brownish in color, they might be useable in packaging paper or for re-use in MDF production. The extract is a mixture of different hemicelluloses and lignin residues. Such crude mixtures show promising stabilization properties as oil-in-water emulsifiers [44] and might be useable in such applications.

The MDF samples show a distinctively different behavior in steam treatments to conventional spruce and poplar wood. Roughly $80 \%$ of the nitrogen compounds is removed from the fibers and can be found either in the extract or in the gaseous phase, depending on the treatment severity. The hydrolysis and subsequent solubilization of the resins lead to an increase in acid content and $\mathrm{pH}$ of the condensed steam (i.e., extract). The changed milieu seems to hamper the hydrolysis of the lignocellulosic polymers. At the same time, for steam treatment characteristics, the degradation products from monomers such as furfural and 5-HMF could not be detected. In both MDF samples, no significant differences between experiments performed at the same severity resulting from different treatment parameter combinations could be observed. Thus, the severity factor used for steam treatment of wood seems to be suitable for the evaluation of steam treatments of waste MDF. This also means that, depending on local economic factors such as unit labor cost and energy prices, a tradeoff between reaction time and temperature can be made. Future investigations may focus on the potential of the fibers for packaging applications and the utilization of hemicelluloses from the extract fraction.

Author Contributions: All authors have read and agree to the published version of the manuscript. Conceptualization, S.H. and B.S.; methodology, S.H.; formal analysis, S.H.; experimental investigation, S.H.; writing-original draft preparation, S.H.; writing-review and editing, S.H. and B.S.; visualization, S.H.; supervision, B.S.; project administration and funding acquisition, B.S. 
Funding: This research was performed in the project FLEXIBI funded in the program FACCE SURPLUS 2 by the PTJ, BMBF based on a decision of the German Parliament, grant number 031B0610.

Acknowledgments: Special thanks to Mark Irle from École supérieure du bois (Nantes, France) for supplying the MDF material.

Conflicts of Interest: The authors declare no conflict of interest.

\section{Appendix A}

Table A1. Fiber and extract yield of poplar, spruce, and MDF sample A and B at treatment severities from 2.47 to 3.95 .

\begin{tabular}{|c|c|c|c|c|c|c|}
\hline & $\underset{\#}{\text { Run }}$ & $\begin{array}{c}\text { Severity } \\
{\left[\log R_{0}\right]}\end{array}$ & $\begin{array}{c}\text { Temperature } \\
{\left[{ }^{\circ} \mathrm{C}\right]}\end{array}$ & $\begin{array}{c}\text { Duration } \\
\text { [min] }\end{array}$ & $\begin{array}{c}\text { Fiber Yield } \\
{[\%]}\end{array}$ & $\begin{array}{c}\text { Extract Yield } \\
{[\%]}\end{array}$ \\
\hline \multirow[t]{10}{*}{ Poplar } & 1 & 2.47 & 150 & 10 & 96.1 & 3.3 \\
\hline & 2 & 2.77 & 150 & 20 & 93.7 & 3.2 \\
\hline & 3 & 2.77 & 160 & 10 & 94.5 & 3.6 \\
\hline & 4 & 3.07 & 160 & 20 & 92.3 & 4.2 \\
\hline & 5 & 3.06 & 170 & 10 & 93.4 & 5.3 \\
\hline & 6 & 3.36 & 170 & 20 & 84.7 & 11.5 \\
\hline & 7 & 3.36 & 180 & 10 & 87.4 & 10.5 \\
\hline & 8 & 3.66 & 180 & 20 & 83.9 & 14.3 \\
\hline & 9 & 3.65 & 190 & 10 & 80.4 & 16.5 \\
\hline & 10 & 3.95 & 190 & 20 & 77.4 & 18.1 \\
\hline \multirow[t]{10}{*}{ Spruce } & 1 & 2.47 & 150 & 10 & 95.9 & 1.9 \\
\hline & 2 & 2.77 & 150 & 20 & 93.7 & 3.1 \\
\hline & 3 & 2.77 & 160 & 10 & 92.6 & 3.4 \\
\hline & 4 & 3.07 & 160 & 20 & 92.0 & 6.0 \\
\hline & 5 & 3.06 & 170 & 10 & 89.2 & 6.2 \\
\hline & 6 & 3.36 & 170 & 20 & 88.0 & 10.4 \\
\hline & 7 & 3.36 & 180 & 10 & 83.9 & 12.1 \\
\hline & 8 & 3.66 & 180 & 20 & 79.9 & 16.5 \\
\hline & 9 & 3.65 & 190 & 10 & 77.4 & 17.5 \\
\hline & 10 & 3.95 & 190 & 20 & 72.6 & 19.6 \\
\hline \multirow[t]{10}{*}{ MDF A } & 1 & 2.47 & 150 & 10 & 85.3 & 12.1 \\
\hline & 2 & 2.77 & 150 & 20 & 84.6 & 12.8 \\
\hline & 3 & 2.77 & 160 & 10 & 82.4 & 13.7 \\
\hline & 4 & 3.07 & 160 & 20 & 82.9 & 14.8 \\
\hline & 5 & 3.06 & 170 & 10 & 81.3 & 13.3 \\
\hline & 6 & 3.36 & 170 & 20 & 77.3 & 17.4 \\
\hline & 7 & 3.36 & 180 & 10 & 78.6 & 16.2 \\
\hline & 8 & 3.66 & 180 & 20 & 74.9 & 16.7 \\
\hline & 9 & 3.65 & 190 & 10 & 73.3 & 19.5 \\
\hline & 10 & 3.95 & 190 & 20 & 72.9 & 18.5 \\
\hline \multirow[t]{10}{*}{ MDF B } & 1 & 2.47 & 150 & 10 & 82.0 & 18.4 \\
\hline & 2 & 2.77 & 150 & 20 & 82.1 & 18.1 \\
\hline & 3 & 2.77 & 160 & 10 & 81.5 & 18.6 \\
\hline & 4 & 3.07 & 160 & 20 & 81.2 & 17.6 \\
\hline & 5 & 3.06 & 170 & 10 & 81.1 & 17.5 \\
\hline & 6 & 3.36 & 170 & 20 & 79.7 & 17.0 \\
\hline & 7 & 3.36 & 180 & 10 & 79.8 & 17.4 \\
\hline & 8 & 3.66 & 180 & 20 & 77.9 & 17.9 \\
\hline & 9 & 3.65 & 190 & 10 & 77.8 & 17.7 \\
\hline & 10 & 3.95 & 190 & 20 & 76.1 & 18.2 \\
\hline
\end{tabular}




\section{References}

1. Irle, M.; Barbu, M.C.; Reh, R.; Bergland, L.; Rowell, R. Wood Composites. In Handbook of Wood Chemistry and Wood Composites, 2nd ed.; Rowell, R.M., Ed.; CRC Press: Boca Raton, FL, USA, 2012; pp. 321-412. ISBN 9781439853818.

2. Deppe, H.-J.; Ernst, K. MDF-Mitteldichte Faserplatten; DRW-Verl.: Leinfelden-Echterdingen, Germany, 1996; ISBN 387181329X.

3. Schneider, T.; Behn, C.; Windeisen-Holzhauser, E.; Roffael, E. Influence of thermo-mechanical and chemo-thermo-mechanical pulping on the properties of oak fibres. Eur. J. Wood Wood Prod. 2019, 77, 229-234. [CrossRef]

4. Suchsland, O.; Woodson, G. Fiberboard Manufacturing Practices in the United States. Agriculture Handbook No. 640; U.S. Department of Agriculture, Forest Service: Washington, DC, USA, 1987.

5. European Panel Federation. Annual Report 2015-2016; European Panel Federation: Brussels, Belgium, 2016.

6. FAO. FAO STAT: Forestry Production and Trade. Available online: http://www.fao.org/faostat/en/\#data/FO (accessed on 24 March 2020).

7. Beele, P. Demonstration of End Uses for Recovered MDF Fibre; Final Report; WRAP (Waste and Resources Action Programe): Banbury, UK, 2009.

8. Irle, M.; Privat, F.; Couret, L.; Belloncle, C.; Déroubaix, G.; Bonnin, E.; Cathala, B. Advanced recycling of post-consumer solid wood and MDF. Wood Mater. Sci. Eng. 2018, 11,1-5. [CrossRef]

9. European Parliament, Council of the European Union. Directive 2008/98/EC of the European Parliament and of The Council of 19 November 2008 on Waste and Repealing Certain Directives; Publications Office of the European Union: Luxembourg, 2008; Available online: https://eur-lex.europa.eu/legal-content/EN/TXT/?uri=celex\% 3A32008L0098 (accessed on 29 March 2020).

10. Förstner, U. Umweltschutztechnik, 6th ed.; Springer: Berlin, Germany, 2004; ISBN 9783540443698.

11. Bundesministerium für Ernährung, Landwirtschaft und Verbraucherschutz (BMELV). Roadmap Bioraffinerien. Im Rahmen der Aktionspläne der Bundesregierung zur Stofflichen und Energetischen Nutzung Nachwachsender Rohstoffe. 2012. Available online: https://www.bmel.de/SharedDocs/Downloads/ Broschueren/RoadmapBioraffinerien.pdf?__blob=publicationFile (accessed on 11 July 2019).

12. Schröder, T.; Lauven, L.-P.; Sowlati, T.; Geldermann, J. Strategic planning of a multi-product wood-biorefinery production system. J. Clean. Prod. 2019, 211, 1502-1516. [CrossRef]

13. Kamm, B.; Kamm, M. Principles of biorefineries. Appl. Microbiol. Biotechnol. 2004, 64, 137-145. [CrossRef] [PubMed]

14. Mantanis, G.I.; Athanassiadou, E.T.; Barbu, M.C.; Wijnendaele, K. Adhesive systems used in the European particleboard, MDF and OSB industries. Wood Mater. Sci. Eng. 2018, 13, 104-116. [CrossRef]

15. Pizzi, A.; Mittal, K.L. Handbook of Adhesive Technology, Revised and Expanded, 2nd ed.; Taylor and Francis: Hoboken, NJ, USA, 2003; ISBN 9780824709860.

16. Lubis, M.A.R.; Hong, M.-K.; Park, B.-D. Hydrolytic removal of cured urea-formaldehyde resins in medium-density fiberboard for recycling. J. Wood Chem. Technol. 2018, 38, 1-14. [CrossRef]

17. Kraft, R. Zur Chemisch-Technologischen Verwertung von Gebrauchten Holzwerkstoffen und Holzrinden; Cuvillier: Göttingen, Germany, 2007; ISBN 978-3-86727-457-9.

18. Franke, R.; Roffael, E. Zum Recycling von Span- und MDF-Platten. Holz Als Roh Und Werkst. 1998, 56, 79-82. [CrossRef]

19. Fleischer, O.; Marutzky, R. Hydrolyse von Harnstoff-Formaldehyd-Harzen: Auflösung des Spangefüges in Holzwerkstoffen durch hydrolytischen Abbau der Leimfuge. Holz Als Roh Und Werkst. 2000, 58, $295-300$. [CrossRef]

20. Roffael, E.; Hüster, H.-G. Complex chemical interactions on thermo hydrolytic degradation of urea formaldehyde resins (UF-resins) in recycling UF-bonded boards. Eur. J. Wood Wood Prod. 2012, 70, 401-405. [CrossRef]

21. Garrote, G.; Dominguez, H.; Parajo, J.C. Mild autohydrolysis: An environmentally friendly technology for xylooligosaccharide production from wood. J. Chem. Technol. Biotechnol. 1999, 1101-1109. [CrossRef]

22. Hu, F.; Ragauskas, A. Pretreatment and lignocellulosic chemistry. Bioenergy Res. 2012, 5, $1043-1066$. [CrossRef] 
23. Saska, M.; Ozer, E. Aqueous extraction of sugarcane bagasse hemicellulose and production of xylose syrup. Biotechnol. Bioeng. 1995, 45, 517-523. [CrossRef]

24. Yang, B.; Wyman, C.E. Pretreatment: The key to unlocking low-cost cellulosic ethanol. Biofuelsbioprod. Bioref. 2008, 2, 26-40. [CrossRef]

25. Baral, N.R.; Shah, A. Comparative techno-economic analysis of steam explosion, dilute sulfuric acid, ammonia fiber explosion and biological pretreatments of corn stover. Bioresour. Technol. 2017, 232, 331-343. [CrossRef] [PubMed]

26. Alén, R. Principles of biorefining. In Biorefining of Forest Resources; Alén, R., Ed.; Finnish Paper Engineers Association/Paperi ja Puu Oy: Helsinki, Finland, 2011; ISBN 952521639X.

27. Schütt, F.; Westereng, B.; Horn, S.J.; Puls, J.; Saake, B. Steam refining as an alternative to steam explosion. Bioresour. Technol. 2012, 111, 476-481. [CrossRef] [PubMed]

28. Overend, R.P.; Chornet, E.; Gascoigne, J.A. Fractionation of lignocellulosics by steam-aqueous pretreatments [and discussion]. Philos. Trans. R. Soc. A Math. Phys. Eng. Sci. 1987, 321, 523-536. [CrossRef]

29. Patel, A.K.; Pandey, A.; Singhania, R.R. Production of celluloytic enzymes for lignocellulosic biomass hydrolysis. In Biofuels: Alternative Feedstocks and Conversion Processes for the Production of Liquid and Gaseous Biofuels, 2nd ed.; Pandey, A., Larroche, C., Gnansounou, E., Khanal, S.K., Dussap, C., Ricke, S., Eds.; Academic Press: Cambridge, MA, USA, 2019; pp. 401-426. ISBN 9780128168561.

30. Puls, J.; Poutanen, K.; Körner, H.-U.; Viikari, L. Biotechnical utilization of wood carbohydrates after steaming pretreatment. Appl. Microbiol. Biotechnol. 1985, 22, 416-423. [CrossRef]

31. Schütt, F.; Haas, N.P.; Dehne, L.; Koch, G.; Janzon, R.; Saake, B. Steam pretreatment for enzymatic hydrolysis of poplar wood: Comparison of optimal conditions with and without $\mathrm{SO}_{2}$ impregnation. Holzforschung 2013, 67, 9-17. [CrossRef]

32. Mackie, K.L.; Brownell, H.H.; West, K.L.; Saddler, J.N. Effect of sulphur dioxide and sulphuric acid on steam explosion of aspenwood. J. Wood Chem. Technol. 1985, 5, 405-425. [CrossRef]

33. Peng, F.; Peng, P.; Xu, F.; Sun, R.-C. Fractional purification and bioconversion of hemicelluloses. Biotechnol. Adv. 2012, 30, 879-903. [CrossRef]

34. Himmel, M.E.; Ding, S.-Y.; Johnson, D.K.; Adney, W.S.; Nimlos, M.R.; Brady, J.W.; Foust, T.D. Biomass recalcitrance: Engineering plants and enzymes for biofuels production. Science 2007, 315, 804-807. [CrossRef]

35. Carvalho, A.F.A.; Marcondes, W.F.; Oliva Neto, P.; Pastore, G.M.; Saddler, J.N.; Arantes, V. The potential of tailoring the conditions of steam explosion to produce xylo-oligosaccharides from sugarcane bagasse. Bioresour. Technol. 2018, 250, 221-229. [CrossRef] [PubMed]

36. Martin-Sampedro, R.; Eugenio, M.E.; Moreno, J.A.; Revilla, E.; Villar, J.C. Integration of kraft pulping on a forest biorefinery by the addition of a steam explosion pretreatment. BioResources 2011, 6, 513-528.

37. Martin-Sampedro, R.; Eugenio, M.E.; Moreno, J.A.; Revilla, E.; Villar, J.C. Integration of a kraft pulping mill into a forest biorefinery: Pre-extraction of hemicellulose by steam explosion versus steam treatment. Bioresour. Technol. 2014, 153, 236-244. [CrossRef] [PubMed]

38. Mikkonen, K.S.; Tenkanen, M. Sustainable food-packaging materials based on future biorefinery products: Xylans and mannans. Trends Food Sci. Technol. 2012, 28, 90-102. [CrossRef]

39. Egüés, I.; Eceiza, A.; Labidi, J. Effect of different hemicelluloses characteristics on film forming properties. Ind. Crop. Prod. 2013, 47, 331-338. [CrossRef]

40. Mendes, F.R.S.; Bastos, M.S.R.; Mendes, L.G.; Silva, A.R.A.; Sousa, F.D.; Monteiro-Moreira, A.C.O.; Cheng, H.N.; Biswas, A.; Moreira, R.A. Preparation and evaluation of hemicellulose films and their blends. Food Hydrocoll. 2017, 70, 181-190. [CrossRef]

41. Yadav, M.P.; Fishman, M.L.; Chau, H.K.; Johnston, D.B.; Hicks, K.B. Molecular characteristics of corn fiber gum and their influence on CFG emulsifying properties. Cereal Chem. J. 2007, 84, 175-180. [CrossRef]

42. Yadav, M.P.; Johnston, D.B.; Hicks, K.B. Structural characterization of corn fiber gums from coarse and fine fiber and a study of their emulsifying properties. J. Agric. Food Chem. 2007, 55, 6366-6371. [CrossRef]

43. Mikkonen, K.S.; Tenkanen, M.; Cooke, P.; Xu, C.; Rita, H.; Willför, S.; Holmbom, B.; Hicks, K.B.; Yadav, M.P. Mannans as stabilizers of oil-in-water beverage emulsions. Lwt Food Sci. Technol. 2009, 42, 849-855. [CrossRef]

44. Lehtonen, M.; Teräslahti, S.; Xu, C.; Yadav, M.P.; Lampi, A.-M.; Mikkonen, K.S. Spruce galactoglucomannans inhibit lipid oxidation in rapeseed oil-in-water emulsions. Food Hydrocoll. 2016, 58, 255-266. [CrossRef] 
45. Mikkonen, K.S.; Kirjoranta, S.; Xu, C.; Hemming, J.; Pranovich, A.; Bhattarai, M.; Peltonen, L.; Kilpeläinen, P.; Maina, N.; Tenkanen, M.; et al. Environmentally-compatible alkyd paints stabilized by wood hemicelluloses. Ind. Crop. Prod. 2019, 133, 212-220. [CrossRef]

46. Bhattarai, M.; Pitkänen, L.; Kitunen, V.; Korpinen, R.; Ilvesniemi, H.; Kilpeläinen, P.O.; Lehtonen, M.; Mikkonen, K.S. Functionality of spruce galactoglucomannans in oil-in-water emulsions. Food Hydrocoll. 2019, 86, 154-161. [CrossRef]

47. Mikkonen, K.S.; Xu, C.; Berton-Carabin, C.; Schroën, K. Spruce galactoglucomannans in rapeseed oil-in-water emulsions: Efficient stabilization performance and structural partitioning. Food Hydrocoll. 2016, 52, 615-624. [CrossRef]

48. Jain, R.K.; Sjöstedt, M.; Glasser, W.G. Thermoplastic xylan derivatives with propylene oxide. Cellulose 2000, 7, 319-336. [CrossRef]

49. Gabrielii, I.; Gatenholm, P.; Glasser, W.G.; Jain, R.K.; Kenne, L. Separation, characterization and hydrogel-formation of hemicellulose from aspen wood. Carbohydr. Polym. 2000, 43, 367-374. [CrossRef]

50. Farhat, W.; Venditti, R.; Quick, A.; Taha, M.; Mignard, N.; Becquart, F.; Ayoub, A. Hemicellulose extraction and characterization for applications in paper coatings and adhesives. Ind. Crop. Prod. 2017, 107, 370-377. [CrossRef]

51. Athanassiadou, E.; Roffael, E.; Mantanis, G. Medium Density Fiberboards (MDF) from Recycled Fibres. In Proceedings of the 2nd European Cost E31 Conference, Bordeaux, France, 29 September-1 October 2005.

52. Roffael, E.; Dix, B.; Behn, C.; Bär, G. Mitverwendung von UF-Harz-gebundenen Gebrauchtspan- und -faserplatten in der MDF-Herstellung. Eur. J. Wood Wood Prod. 2010, 68, 121-128. [CrossRef]

53. Roffael, E.; Behn, C.; Schneider, T.; Krug, D. Bonding of recycled fibres with urea-formaldehyde resins. Int. Wood Prod. J. 2016, 7, 36-45. [CrossRef]

54. Moezzipour, B.; Ahmadi, M.; Abdolkhani, A.; Doosthoseini, K. Chemical changes of wood fibers after hydrothermal recycling of MDF wastes. J. Indian Acad Wood Sci 2017, 14, 133-138. [CrossRef]

55. Moezzipour, B.; Abdolkhani, A.; Doost-hoseini, K.; Ahmad Ramazani, S.A.; Tarmian, A. Practical properties and formaldehyde emission of medium density fiberboards (MDFs) recycled by electrical method. Eur. J. Wood Wood Prod. 2018, 76, 1287-1294. [CrossRef]

56. Ihnat, V.; Lubke, H.; Russ, A.; Pazitny, A. Waste agglomerated wood materials as a secondary raw material for chipboards and fiberboards: Part II. Preparation and characterization of wood fibers in terms of their reuse. Wood Res. 2018, 63, 431-442.

57. Adeeb, E.; Kim, T.W.; Sohn, C.H. Cost-benefit analysis of medium- density fiberboard production by adding fiber from recycled medium-density fiberboard. For. Prod. J. 2018, 68, 414-418. [CrossRef]

58. Couret, L.; Irle, M.; Belloncle, C.; Cathala, B. Extraction and characterization of cellulose nanocrystals from post-consumer wood fiberboard waste. Cellulose 2017, 24, 2125-2137. [CrossRef]

59. Gu, J.; Hu, C.; Zhong, R.; Tu, D.; Yun, H.; Zhang, W.; Leu, S.-Y. Isolation of cellulose nanocrystals from medium density fiberboards. Carbohydr. Polym. 2017, 167, 70-78. [CrossRef]

60. Kang, Y.-R.; Hwang, J.-S.; Bae, K.-H.; Cho, H.-H.; Lee, E.-J.; Cho, Y.-S.; Nam, K.-D. Pretreatment and enzymatic saccharification of wasted MDF for bioethanol production. Ksbb J. 2015, 30, 332-338. [CrossRef]

61. Kang, Y.-R.; Hwang, J.-S.; Bae, K.-H.; Cho, H.-H.; Lee, E.-J.; Cho, Y.-S.; Nam, K.-D. Bioethanol production by using wasted MDF. KSBB J. 2016, 31, 73-78. [CrossRef]

62. Park, Y.-K.; Park, K.-S.; Park, S.H. Fast pyrolysis of medium-density fiberboard using a fluidized bed reactor. Appl. Chem. Eng. 2013, 24, 672-675. [CrossRef]

63. Han, T.U.; Kim, Y.-M.; Watanabe, C.; Teramae, N.; Park, Y.-K.; Kim, S.; Lee, Y. Analytical pyrolysis properties of waste medium-density fiberboard and particle board. J. Ind. Eng. Chem. 2015, 32, 345-352. [CrossRef]

64. Chaharmahali, M.; Tajvidi, M.; Najafi, S.K. Mechanical properties of wood plastic composite panels made from waste fiberboard and particleboard. Polym. Compos. 2008, 29, 606-610. [CrossRef]

65. Bütün, F.Y.; Mayer, A.K.; Ostendorf, K.; Gröne, O.-E.Z.; Krause, K.C.; Schöpper, C.; Mertens, O.; Krause, A.; Mai, C. Recovering fibers from fiberboards for wood polymer composites production. Int. Wood Prod. J. 2018, 52, 1-8. [CrossRef]

66. Bütün, F.Y.; Sauerbier, P.; Militz, H.; Mai, C. The effect of fiberboard (MDF) disintegration technique on wood polymer composites (WPC) produced with recovered wood particles. Compos. Part A Appl. Sci. Manuf. 2019, 118, 312-316. [CrossRef] 
67. Czarnecki, R.; Dziurka, D.; Lecka, J. The use of recycled boards as the substitute for particles in the centre layer of particleboards. Electron. J. Pol. Agric. Univ. Ser. Wood Technol. 2003, 6, 1.

68. Tunc, M.S.; van Heiningen, A.R.P. Hydrothermal dissolution of mixed southern hardwoods. Holzforschung 2008, 62, 613. [CrossRef]

69. Rissanen, J.V.; Murzin, D.Y.; Salmi, T.; Grénman, H. Aqueous extraction of hemicelluloses from spruce-From hot to warm. Bioresour. Technol. 2016, 199, 279-282. [CrossRef] [PubMed]

70. Pranovich, A.; Holmbom, B.; Willför, S. Two-stage hot-water extraction of galactoglucomannans from spruce wood. J. Wood Chem. Technol. 2016, 36, 140-156. [CrossRef]

71. Franke, R.; Roffael, E. Zum recycling von span- und MDF-platten. Holz Als Roh Und Werkst. 1998, 56, 381-385. [CrossRef]

72. Lorenz, D.; Erasmy, N.; Akil, Y.; Saake, B. A new method for the quantification of monosaccharides, uronic acids and oligosaccharides in partially hydrolyzed xylans by HPAEC-UV/VIS. Carbohydr. Polym. 2016, 140, 181-187. [CrossRef]

73. Maekawa, E.; Ichizawa, T.; Koshijima, T. An Evaluation of the acid-soluble lignin determination in analyses of lignin by the sulfuric acid method. J. Wood Chem. Technol. 1989, 9, 549-567. [CrossRef]

74. Grigsby, W.J.; Carpenter, J.E.P.; Sargent, R. Investigating the extent of urea formaldehyde resin cure in medium density fiberboard: Resin extractability and fiber effects. J. Wood Chem. Technol. 2014, 34, 225-238. [CrossRef]

75. Kraft, R.; Edmone, R. Thermohydrolytischer abbau von mitteldichten faserplatten. Adhäsion Kleb. Dicht. 2003, 47, 38-41. [CrossRef]

76. Eslyn, W.E. Outside storage of hardwood chips in the northeast II. Microbiological effects. Tappi 1967, 50, 297-303.

77. Jirjis, R.; Theander, $\mathrm{O}$. The effect of seasonal storage on the chemical composition of forest residue chips. Scand. J. For. Res. 1990, 5, 437-448. [CrossRef]

78. Winandy, J.E.; Krzysik, A.M. Thermal degradation of wood fibers during hot-pressing of MDF composites. Part I, Relative effects and benefits of thermal exposure. Wood Fiber Sci. 2007, 39, 450-461.

79. Kelley, S.S.; Elder, T.; Groom, L.H. Changes in the chemical composition and spectroscopy of loblolly pine medium density fiberboard furnish as a function of age and refining pressure. Wood Fiber Sci. 2005, 37, 14-22.

80. Alén, R. Structure and chemical composition of biomass feedstocks. In Biorefining of Forest Resources; Finnish Paper Engineers Association/Paperi ja Puu Oy: Helsinki, Finland, 2011; pp. 18-54. ISBN 952521639X.

81. Fengel, D.; Wegener, G. Wood. Chemistry, Ultrastructure, Reactions; Walter de Gruyter: Berlin, NY, USA, 1983; ISBN 3-11-008481-3.

82. Bobleter, O. Hydrothermal degradation of polymers derived from plants. Prog. Polym. Sci. 1994, 19, 797-841. [CrossRef]

83. Schütt, F.; Puls, J.; Saake, B. Optimization of steam pretreatment conditions for enzymatic hydrolysis of poplar wood. Holzforschung 2011, 65. [CrossRef]

84. Chornet, E.; Overend, R.P. Phenomological Kinetics And Reaction Engineering Aspects Of Steam/Aqueous Treatments. In Steam Explosion Techniques: Fundamentals and Industrial Applications, In Proceedings of the International Workshop on Steam Explosion Techniques: Fundamentals and Industrial Applications, Milan, Italy, 20-21 October 1988; Focher, B., Marzetti, A., Crescenzi, V., Eds.; Gordon and Breach Science Publishers: New York, NY, USA, 1991; pp. 22-58. ISBN 9782881244575.

85. Garrote, G.; Domínguez, H.; Parajó, J.C. Study on the deacetylation of hemicelluloses during the hydrothermal processing of Eucalyptus wood. Holz. Als. Roh. Werkst. 2001, 59, 53-59. [CrossRef]

86. Heinze, T.T. Polysaccharides I. Structure, Characterisation and Use; Springer-Verlag GmbH: Berlin/Heidelberg, Germany, 2005; ISBN 9783540261124.

87. Hu, F.; Jung, S.; Ragauskas, A. Pseudo-lignin formation and its impact on enzymatic hydrolysis. Bioresour. Technol. 2012, 117, 7-12. [CrossRef] [PubMed]

88. Sannigrahi, P.; Kim, D.H.; Jung, S.; Ragauskas, A. Pseudo-lignin and pretreatment chemistry. Energy Environ. Sci. 2011, 4, 1306-1310. [CrossRef]

89. Shinde, S.D.; Meng, X.; Kumar, R.; Ragauskas, A.J. Recent advances in understanding the pseudo-lignin formation in a lignocellulosic biorefinery. Green Chem. 2018, 20, 2192-2205. [CrossRef]

90. Packman, D.F. The acidity of wood. Holzforschung 1960, 14, 178-183. [CrossRef] 
91. Larsson, S.; Palmqvist, E.; Hahn-Hägerdal, B.; Tengborg, C.; Stenberg, K.; Zacchi, G.; Nilvebrant, N.-O. The generation of fermentation inhibitors during dilute acid hydrolysis of softwood. Enzym. Microb. Technol. 1999, 24, 151-159. [CrossRef]

92. Ulbricht, R. A review of 5-hydroxymethylfurfural (HMF) in parenteral solutions. Fundam. Appl. Toxicol. 1984, 4, 843-853. [CrossRef]

93. Fengel, D.; Wegener, G.; Feckl, J. Beitrag zur Charakterisierung analytischer und technischer Lignine. Teil 2. Physikalisch-chemische und elektronenmikroskopische Untersuchungen. Holzforschung 1981, 35, 111-118. [CrossRef]

Sample Availability: Samples of the compounds are not available from the authors.

(C) 2020 by the authors. Licensee MDPI, Basel, Switzerland. This article is an open access article distributed under the terms and conditions of the Creative Commons Attribution (CC BY) license (http://creativecommons.org/licenses/by/4.0/). 